\title{
A hierarchy of disability rights? A comparative examination of the regulation of digital television in the United States of America and the United Kingdom
}

\author{
Dr Eliza VARNEY*
}

Keele University

\begin{abstract}
Introduction
I nformation and communication technologies (ICTs) play an increasingly important role in everyday life. ${ }^{1}$ For disabled people, technological advances are particularly important, as they can contribute towards facilitating independent living. ${ }^{2}$ Technological developments include the proliferation of new services for accessing digital television such as audio description (video description), closed signing 3 and the availability of subtitles (captions) in live broadcasts, enabled by new speech-to-text technologies. ${ }^{4}$ Effective access to information can be crucial in enabling participation in society as citizens. ${ }^{5}$ Unfortunately, disabled people still face significant barriers in accessing digital television, including, among other things, the use of multiple remote controls and the provision of difficult to navigate on-screen displays. ${ }^{6}$ Although these access barriers have the potential to affect a considerable number of disabled people, legislative responses tend to concentrate on assisting people with sensory disabilities, often overlooking the needs of people with dexterity or cognitive disabilities. ${ }^{7}$ Whilst ensuring an effective protection for people with sensory disabilities is important, it is disappointing that people with cognitive and dexterity disabilities are not given a stronger degree of protection. It can, therefore, be argued that we are faced with a hierarchy of disability rights in the digital television sector.
\end{abstract}

* Lecturer in Law, Keele University. I would like to thank Mike Varney, Ruth Fletcher, Jim Chen, Ani Satz and the anonymous referees for constructive comments on an earlier draft of this article. Any errors and omissions are, of course, my own. The issues discussed in this article will be developed in a forthcoming book: Disability and Information Technology: A comparative study in media regulation (Cambridge: CUP).

1 Measuring Progress of eAccessibility in Europe (MeAC), Assessment of the Status of eAccessibility in Europe: Main Report (2007).

2 E L Myers III, "Disability and technology" (2004) 65 Montana Law Review 289-307, at p. 290.

3 Closed signing allows the public to switch the sign interpreter on and off. See M George and L Lennard, "Ease of use issues with domestic electronic communications equipment” (2007), para. 4.17, www.ofcom.org.uk/research/tv/reports/easeofuse/easeofuse.pdf.

4 MeAC, Main Report, n. 1 above, p. 49.

5 M Feintuck and M Varney, Media Regulation, Public Interest and the Law 2nd edn (Edinburgh: Edinburgh UP 2006), p. 250.

6 George and Lennard, "Closed signing", n. 3 above.

7 MeAC, Main Report, n. 1 above, p. 49. 
This article aims to explore the protection of disability rights in the regulation of digital television in the United States of America and the United Kingdom, in view of assessing whether a hierarchy of disability rights exists in these jurisdictions. The study adopts a comparative approach to determine whether regulators across the Atlantic are confronted with similar challenges and whether similar solutions are adopted to address these challenges. Part one highlights the importance of ICTs in the lives of disabled people and focuses on the idea of access to information as a tool for enabling people to participate in society as citizens. This article relies on a definition of disability focused on the social barriers faced by disabled people rather than on their medical conditions. ${ }^{8}$ Parts two and three explore the protection of disability rights in the regulation of digital television in the United States of America and the United Kingdom respectively. Part four discusses the importance of a regulatory framework for the electronic communications sector focused on safeguarding citizenship values such as equality and dignity and stresses that in a regulatory framework genuinely committed to protecting equality of citizenship, there is no room for any hierarchy in the protection of disability rights.

\section{Rights of access to ICTs for people with disabilities}

ICTs have become central to people's lives. ${ }^{9}$ As Goggin and Newell suggest, "technology is present in everyday life in ways that we often do not notice once we become accustomed to and reliant upon it". ${ }^{10}$ Developments such as closed captioning, closed signing and audio description have the potential to improve the lives of disabled people and to contribute towards independent living. ${ }^{11}$ At the same time, advances in ICTs have brought an increased level of complexity due, inter alia, to the provision of difficult to navigate on-screen displays and the use of multiple remote controls. ${ }^{12}$ The United States Department of Justice has stressed that "information technology can empower the lives of disabled people if it is accessible, or further segregate them from mainstream if it is not". ${ }^{13}$ A number of accessibility provisions need to be put in place to ensure that disabled people can have equal access to digital television. For example, people with visual disabilities could benefit from the provision of audio description, which consists of an additional channel that describes the video content transmitted. ${ }^{14}$ People with hearing disabilities could benefit from the provision of sign language interpretation or from the closed captioning of digital television programming. ${ }^{15}$ For people with dexterity disabilities, accessibility solutions could include the design of keypads with better-spaced buttons. ${ }^{16}$ People with cognitive disabilities could benefit, for instance, from the design of easy to use remote controls and easy to navigate on-screen displays. ${ }^{17}$

Such measures are designed to address the barriers faced by disabled people in accessing ICTs. Equality of access to information plays an important role in enabling the participation

8 M Connolly, Discrimination Law (London: Sweet \& Maxwell 2006), p. 299.

9 G Goggin and C Newell, Digital Disability: The social construction of disability in new media (Lanham, MD: Rowman \& Littlefield 2003), p. 4.

10 Ibid., p. 3.

11 B M Sullenger, "Comment: Telecommuting: a reasonable accommodation under the Americans with Disabilities Act as technology advances” (2007) 19 Regent University Law Review 537-60, at p. 537.

12 George and Lennard "Closed signing", n. 3 above.

13 USDJ, "Section 508 of the Rehabilitation Act: Accessibility for people with disabilities in the information age" (2008).

14 MeAC, Main Report, n. 1 above, p. 4.

15 Ibid., p. 5.

16 Ibid., p. 6.

17 Ibid. 
of disabled people in civil society as citizens. ${ }^{18}$ Gregg stresses that "access to technology is one determinant of who can participate in the social, cultural, political and economic facets of a society", 19 while Feintuck and Varney suggest that effective access to information is "a prerequisite for any meaningful concept of citizenship". ${ }^{20}$ It is important that regulatory measures for the digital television sector reflect a perception of disabled people not just as consumers but also as citizens. The notion of consumer reflects a narrow perception of the public as economic actors in the pursuit of self-interest, who would benefit from lower prices, increased choice and increased quality of products. ${ }^{21}$ On the other hand, the citizenship notion is much wider and comprises democratic values such as the protection of human dignity and equality between all members of society. 22 When acting as citizens, people participate within the wider social and political sphere and tend to take into account the interests of others. ${ }^{23}$ The citizenship values of equality and dignity should, therefore, play an important role in any regulatory framework for the digital television sector.

Measures designed to tackle access barriers in the digital television sector reflect a social definition of disability. Unlike the medical approach, which focuses on the physical or mental impairments of disabled people, the social model is concerned with the "social barriers" faced by disabled people. ${ }^{24}$ While the medical model assumes that one of the "primary problem $[\mathrm{s}]$ " faced by disabled people is "[their] incapacity to participate in society", 25 the social model points towards the failure of society to construct environments which take into account disabilities. ${ }^{26}$ The American National Council on Disability (NCD) highlights that "people with almost every type of disability encounter barriers" to accessing ICTs. ${ }^{27}$ These access barriers are likely to affect a considerable number of people, as it is estimated that "approximately 20 per cent of all people live with a disability". 28 These barriers can be traced, inter alia, to general challenges to equal opportunity and independent living (given that, statistically, disabled people tend to have fewer resources than others and this perpetuates disparities in opportunity) ${ }^{29}$ as well as to the poor design of ICTs. ${ }^{30}$ Ultimately, these accessibility barriers can result in isolation ${ }^{31}$ and a sense of dependency and frustration. 32

Even when provisions are put into place to facilitate the access of disabled people to ICTs, these tend to reflect a hierarchy of disabilities. Regulatory efforts are mainly focused

18 European Commission, "Challenges for European information society beyond 2005”, COM (2004) 757, p. 6.

19 J L Gregg, "Policy-making in the public interests: a contextual analysis in the passage of closed-captioning policy" (2006) 21(5) Disability and Society 537-50, at p. 537.

20 Feintuck and Varney, Media Regulation, n. 5 above, p. 250.

21 M Feintuck, "The Public Interest" in Regulation (Oxford: OUP 2004).

22 Ibid.

23 C R Sunstein, After the Rights Revolution: Reconceiving the regulatory state (Cambridge, Mass: Harvard UP 1990), p. 58.

24 D Chalmers et al., European Union Law (Cambridge: CUP 2006), p. 891.

25 R Scotch, "Models of disability and the Americans with Disabilities Act" (2000) 21 Berkeley Journal of Employment and Labor Law 213-22. at p. 214.

26 K Monaghan, Equality Law (Oxford: OUP 2007), para 1.21.

27 NCD, "When the Americans with Disabilities Act goes online: application of the ADA to the internet and the worldwide web" (2003) Position Paper.

28 Goggin and Newell, Digital Disability, n. 9 above, p. xv.

29 NCD, "When the ADA goes online", n. 27 above.

30 Ibid.

31 Scotch, "Models of Disability", n. 25 above, pp. 43-4.

32 European Commission, "Ageing well in the information society: an i2010 initiative", COM (2007) 332 , p. 5. 
towards the protection of people with sensory disabilities (e.g. visual and/or hearing), through the adoption of measures concerned with accessibility services such as subtitling, signing and audio description. At the same time, the interests of people with dexterity disabilities and cognitive disabilities, such as learning disabilities, are often overlooked in the regulation of the ICT sector. As Campbell suggests, "the disability community is not immune from the same stereotypical attitudes about different disabilities that affect the non disabled community". ${ }^{33}$ In fact, "there is a hierarchy of disabilities within the community itself" and people with cognitive disabilities are "among the most stigmatised, even amongst those with disabilities". 34 The following two sections explore the extent to which this hierarchy of disabilities is reflected in the regulation of digital television in the USA and the UK.

\section{The protection of disability rights in the regulation of digital television in the United States of America}

In the American system, the protection of disability rights in the digital television sector tends to concentrate on safeguarding the rights of people with sensory disabilities, often overlooking the rights of people with dexterity and cognitive disabilities. It is regrettable that people with cognitive and dexterity disabilities are not given a stronger degree of protection, especially given the commitment of broadcasters to comply with "public interest" obligations. ${ }^{35}$ Broadcast licensees are regarded as "public trustees" and, in exchange for the right to broadcast over a channel of publicly owned radiofrequency spectrum, they are required to "broadcast in furtherance of the "public interest, convenience and necessity". 36 What exactly constitutes "public interest" programming was left to be defined by the regulators. ${ }^{37}$ However, as Varona indicates, the American communications regulator, the Federal Communications Commission (FCC) has failed to put forward a coherent definition of the "public interest" in the broadcasting context. ${ }^{38}$ In the specific "public interest" obligations imposed on broadcasters, Congress has drawn a link between these obligations and the protection of disability rights in the communications sector. ${ }^{39}$ Yet, these provisions are limited to enhancing television access for people with sensory disabilities through the use of closed captions and other assistive technologies. 40 This limited level of protection conferred upon disabled people is disappointing, given the strong link between the "public interest" concept and the protection of citizenship rights. ${ }^{41}$ As Feintuck suggests, the value base for interpreting the "public interest" notion should comprise the "democratic imperatives that underlie our society", including the protection of equality and human dignity. 42

33 J Campbell, "Unintended consequences in public policy: persons with psychiatric disabilities and the Americans with Disabilities Act” (1994) 22(1) Policy Studies Journal 133-46, at p. 134.

34 Ibid.

35 Communications Act 1934, as amended, 47 USC, s. $301 \mathrm{ff}$.

36 Ibid. See A E Varona, "Changing channels and bridging divides: the failure and redemption of American broadcast television regulation” (2004) 6(1) Minnesota Journal of Law, Science and Technology 1-116, at pp. 3-4.

37 A E Varona, "Out of thin air: using First Amendment public forum analysis to redeem American broadcasting regulation” (2006) 39(2) University of Michigan Journal of Law Reform 149-98, at p. 151.

38 Ibid.

3947 USC, s. 613 (Supp. V. 1999). See D P Graham, "Public interest regulation in the digital age" (2003) 11 Communications Law Conspectus 97-144, at p. 107.

40 Ibid.

41 Feintuck, The Public Interest, n. 21 above, p. 28.

42 Ibid., p. 58. 
The key provision safeguarding the rights of people with hearing and visual disabilities in the digital television sector is s. 713 of the Telecommunications Act $1996 .{ }^{43}$ For people with hearing disabilities, s. $713(\mathrm{a}-\mathrm{e})$ empowers the FCC to adopt regulations requiring closed captions for television programmes. ${ }^{44}$ Closed captions enable people with hearing disabilities to access television programming "by displaying the audio portion of a television program as text on the television screen". ${ }^{45}$ Under s. $79(1)$ of the Telecommunications Act, by the beginning of 2006, all new programming (i.e. programming broadcast on or after 1 January 1998) is expected to be broadcast with closed captions. ${ }^{46}$ Furthermore, 75 per cent of pre-rule programming (i.e. programming broadcast before 1 January 1998) is expected to be broadcast with closed captions by the beginning of $2008 .{ }^{47}$ Certain categories of programming (such as programming broadcast between 2am and 6am local time) are exempted from these provisions. ${ }^{48}$ Furthermore, the FCC can waive the closed captioning requirement if this imposes an "undue burden" on the programming provider" 49 (i.e. if the captioning requirement would cause "significant difficulty or expense"). ${ }^{50}$ Although there is no evidence to suggest that this provision has had a detrimental effect on the availability of closed-captioned programming, 51 the "undue burden" defence illustrates how costrelated considerations constitute potential barriers for an increased level of access for disabled people to ICTs.

Closed captions are displayed by television receivers through either the use of a set-top box (STB) decoder or an integrated decoder circuitry. ${ }^{52}$ The integrated decoder circuitry is preferable to a separate decoder, due to the cost implications and the installation requirements of the latter. ${ }^{53}$ In 1990, Congress adopted the Television Decoder Circuitry Act (TDCA), ${ }^{54}$ which requires all television receivers with screens of 13 inches or larger to contain built-in decoder circuitry for the display of closed captions. 55 The TDCA has been praised for enabling millions of people with hearing disabilities to access broadcast information" 56 and for acknowledging that "for many disabled people, access to technological media lies at the heart of economic advancement and social integration". 57 Organisations representing the interests of people with hearing disabilities have called for a stricter enforcement of the TDCA, arguing that captioned text is "often filled with errors and terminated before the end of the program" and that this has a negative effect on the ability of people with hearing disabilities to access information effectively. ${ }^{58}$

4347 USC, s. 613 (2004).

44 Ibid. See Myers, "Disability and technology", n. 2 above, p. 291.

45 FCC, "Closed captioning" (2008) Consumer Fact Sheet, 29 October.

4647 CFR, s. 79(1)(a) (2004).

47 Ibid.

48 Ibid., s. 79(1)(d); MeAC, Assessment of the Status of eAccessibility in Europe: Policy inventory (2007), p. 263.

4947 CFR, s. $79(1)(d)(2)$.

50 Ibid., s. $79(1)(\mathrm{f})(2)$.

51 Myers, "Disability and technology", n. 2 above, p. 291.

52 FCC, "Closed captioning", n. 45 above.

53 Gregg, "Policy making", n. 19 above, p. 547.

54 Public Law 101-31, 104 stat. 960 (1990).

55 MeAC, Policy Inventory, n. 48 above, p. 264.

56 E J Markey, "Electronic oases take root in Mr Minow's vast wasteland" (2003) 55(3) Federal Communications Law Journal 545-52, at p. 547.

57 A M Schloss, "Web-sight for visually-disabled people: does Title III of the Americans with Disabilities Act apply to internet websites?” (2001) 35(1) Columbia Journal of Law and Social Problems, pp. 35-59, at p. 48.

58 Gregg, "Policy-making”, n. 19 above, p. 546. 
Unlike the provisions for closed captioning under s. $713(\mathrm{a}-\mathrm{e})$ of the Telecommunications Act 1996, ${ }^{9}$ the provisions for video description under s. $713(\mathrm{f}-\mathrm{g})$ designed to assist people with visual disabilities, are much weaker. ${ }^{60}$ Video description technology provides people with visual disabilities with aural descriptions of the key visual elements in a television programme. ${ }^{61}$ While Congress required the FCC to adopt closedcaptioning regulations, ${ }^{62}$ the requirements imposed with regards to video description are limited to the preparation of a report by the FCC to Congress. ${ }^{63}$ Despite these limitations, the FCC proceeded to adopt rules on video description, with the aim of facilitating the access of people with visual disabilities to television programming. ${ }^{64}$ These rules required major network and cable channels in the top 25 to broadcast a minimum of four hours per week of described programming. ${ }^{65}$ These rules were challenged by the industry (on grounds that Congress did not entrust the FCC with the adoption of video description rules) and were ultimately struck down by a ruling of the United States Court of Appeals for the District of Columbia Circuit in Motion Picture Association of America v FCC. ${ }^{66}$

All of these difficulties could have been avoided if s. 713 of the Telecommunications Act 1996 had been adopted in its original format, as presented in the House of Representatives, which included a provision empowering the FCC to adopt video description rules. ${ }^{67}$ The ultimate version of s. 713 was watered down, removing this authority from the FCC. ${ }^{68}$ It is regrettable that Congress has treated closed captioning and video description differently, providing people with visual disabilities with a lesser degree of protection than people with hearing disabilities. A Bill to reinstate the FCC requirements on video description ${ }^{69}$ has been put forward before Congress. ${ }^{70}$ However, even if the FCC rules on video description are ultimately reinstated, it is doubtful that four hours of described programming per week constitutes a genuine commitment to ensuring that people with visual disabilities benefit from equal access to programming. Some organisations representing the interests of people with visual disabilities have expressed opposition to this Bill, unless an amendment is introduced "to require a process that will lead to the voicing of text printed on the screen". ${ }^{71}$ Ensuring effective access to programming for people with visual disabilities is seen as "a matter of . . f fairness", as "video description is for the blind people what closed captioning is for those who are deaf". ${ }^{72}$ Such provisions would avoid the risk of a hierarchy of protection for people with sensory disabilities.

According to Myers, an increased level of protection for people with visual disabilities in accessing digital television could be provided if Congress amended s. 255 of the

5947 USC, s. 613(a-e) (2004).

60 Ibid., s. 613(f-g).

61 Motion Picture Association of America, Inc. et al. v Federal Communications Commission et al. 309 F3d 796, 8 November 2002.

6247 USC, s. 613(b-c) (2004).

63 Ibid., s. 613(f-g). See Motion Picture Association, n. 61 above.

64 FCC, "Implementation of video description of video programming, report and order" (2000) 15 FCCR 230.

65 MeAC, Policy Inventory, n. 48 above, p. 264.

66 Motion Picture Association, n. 61 above.

67 Ibid.

68 Ibid.

69 HR 951 Video Description Restoration Act 2005.

70 MeAC, Policy Inventory, n. 48 above, p. 264.

71 S Maneki, "Imagining a brighter future for blind Americans: a report on the 2005 convention resolutions" (2005 August/September) The Braille Monitor.

72 American Council of the Blind, "The American Council of the Blind answers your questions about video description and the Video Description Restoration Act". 
Telecommunications Act 1996 to include video description services. ${ }^{73}$ Section 255 requires manufacturers of telecommunications equipment and service providers to ensure that their equipment is accessible and usable by disabled people. ${ }^{74}$ However, this requirement applies only if accessibility is "readily achievable" 75 (i.e. if accessibility can be ensured without much difficulty or expense). ${ }^{76}$ In determining whether accessibility is "readily achievable", the FCC makes assessments on a case-by-case basis, balancing accessibility costs with the available resources of a particular market player. ${ }^{77}$ In implementing s. 255, the FCC seems to be more favourable to industry interests, often at the expense of the interests of disabled people. ${ }^{78}$ As Kanayama points out, the FCC regulations implementing s. 255 rely on voluntary efforts by the telecommunications industry limited to encouraging it to adopt accessibility solutions. ${ }^{79}$ Therefore, while an extension of s. 255 to cover video description services would be beneficial in facilitating the access of people with visual disabilities to digital television, ${ }^{80}$ such a provision will only have a genuine impact in assisting disabled people if the FCC moves away from the "pro-industry regulatory bias" affecting the telecommunications industry. ${ }^{81}$

The specific provisions adopted for the television sector seem to be focused on assisting people with hearing disabilities and to a lesser extent people with visual disabilities, overlooking the needs of people with dexterity and cognitive disabilities. The remainder of this section focuses on the general equality provisions, particularly the Americans with Disabilities Act (ADA), ${ }^{82}$ assessing the extent to which these provisions assist disabled people in accessing digital television. The ADA is the main piece of legislation adopted in the United States of America for combating disability discrimination. The Act aims to guarantee equality of opportunities for disabled people in a number of sectors, including employment (Title I), ${ }^{83}$ public services (Title II), ${ }^{84}$ places of public accommodation (Title III) ${ }^{85}$ and telecommunications (Title IV). ${ }^{86}$ The ADA is designed, inter alia, "to provide a clear and comprehensive national mandate for the elimination of discrimination against individuals with disabilities" and "to provide clear, strong, consistent, enforceable standards addressing discrimination against individuals with disabilities". ${ }^{87}$ The enactment

73 Myers, "Disability and technology", n. 2 above, p. 307.

7447 USC, s. 255(c) (2004).

75 Ibid., s. 255(a)(2).

7647 CFR, s. 6.3(g) (2004). See Myers, "Disability and technology", n. 2 above, p. 293.

77 Myers, "Disability and technology", n. 2 above, p. 293; FCC, "Section 255 telecommunications access for people with disabilities" (2008b) Consumer Fact Sheet, 8 October.

78 T Kanayama, "Leaving it all up to industry: people with disabilities and the Telecommunications Act of 1996" (2003) 19 Information Society 185-94, at p. 185.

79 Ibid.

80 Myers, "Disability and technology", n. 2 above, p. 307.

81 Kanayama, "Leaving it", n. 78 above, p. 185.

8242 USC, s. $12101 \mathrm{ff}$.

83 Ibid., ss. 12111-17.

84 Ibid., ss. 12131-65.

85 Ibid., ss. 12181-9.

8647 USC, ss. 225 and 611.

8742 USC, s 12101(b)(1) and (2). The provisions under the ADA are supplemented by statutes under state law. However, an examination of the provisions under state law is outside the scope of the present research. 
of the ADA has led to both "physical changes" (such as accessible public facilities) and "fundamental changes in public attitudes" towards disabled people. ${ }^{88}$

While an earlier version of the ADA included provisions applicable to the television sector (including the development and operation under "appropriate circumstances" of assistive technologies such as captioning and audio information), ${ }^{89}$ these provisions were subsequently left out of the final version of the Act ${ }^{90}$ and the provisions dealing specifically with the communications sector were limited to telecommunications relay services for people with hearing and speech disabilities ${ }^{91}$ and closed captioning on public service announcements. ${ }^{92}$ The adoption of a watered-down version of the communications provisions in the ADA is believed to be the result of concerns that the Act would face opposition in Congress, as a result of lobbying from the broadcasting industry. ${ }^{93}$ This is unsatisfactory, as it illustrates the influence exercised by the industry over policy making, ${ }^{94}$ often at the expense of the interests of the public. ${ }^{95}$ Although the ADA was ultimately complemented by the adoption of the TDCA, the inclusion of access provisions for the broadcasting sector in the ADA would have sent the message that access to this sector is an integral part of the process of combating the social barriers faced by disabled people and for promoting equality between all citizens. The incorporation of provisions regarding the television sector in the ADA would have also benefited from the social model reflected in this instrument. The ADA seeks to eliminate discrimination and to tackle the barriers faced by disabled people 96 and reflects the "emergence of a new socio-political consciousness about disability". ${ }^{97}$ It is indeed regrettable that the provisions facilitating the access of disabled people to the television sector have been left out of the final version of the ADA, as the social model of disability reflected in this instrument could have led to a stronger commitment to tackling the barriers faced by disabled people in the communications sector.

However, even if the ADA were applicable to the digital television sector, the limitations in Title IV of the Act render questionable the effectiveness of these provisions in tackling the access barriers faced by disabled people. Unlike the provisions under Titles I-III, which are concerned with safeguarding the interests of all disabled people, the protection conferred by Title IV is confined to people with hearing and speech disabilities. ${ }^{98}$ This limitation is unsatisfactory, given that the ADA relies on a wide definition of disability which includes physical or mental impairments, a record of such impairments and perceived disability. ${ }^{99}$ The limited application of Title IV is in strong contrast to the objectives of the $\mathrm{ADA}$, which are, among others, to ensure the "equality of opportunity, full participation,

88 J Bick, "Americans with Disabilities Act and the internet" (2000) 10(2) Albany Law Journal of Science and Technology 205-27, at p. 207.

89 HR 4498, s. 8(h)(3).

90 R Colker, "ADA Title III: a fragile compromise" (2000) 21 Berkeley Journal of Employment and Labor Law $377-412$, at n. 39.

9147 USC, s. 225. Relay services "enable hearing and speech impaired people who use devices that translate voice signals into written messages, to communicate with people who do not possess such special devices". See Schloss, "Web-sight", n. 57 above, p. 48.

9247 USC, s. 611.

93 Gregg, "Policy-making”, n. 19 above, p. 543.

94 Varona, "Changing channels", n. 36 above.

95 E Varney, "Regulating the digital television infrastructure in the EU. Room for citizenship interests?" (2006) 3(3) SCRIPT-ed 221-42.

96 Scotch, "Models of disability", n. above 25, p. 214.

$97 \mathrm{~J}$ A Nelson, The Disabled, the Media and the Information Age (Westport: Greenwood Press 1994), at p. 4.

9847 USC, s. 225.

9942 USC, s. 12102. 
independent living, and economic self-sufficiency" necessary to enable disabled people to access goods and services to the same extent as everyone else. ${ }^{100}$ Finnigan et al. indicate that the provisions under Title IV are "narrowly tailored", 101 while Bowe points out that Title IV of the ADA is "the only section of the Act that protects only part, not all of the population of Americans with a disability". ${ }^{102}$ In concentrating its protection only on people with hearing or speech disabilities, Title IV overlooks the needs of people with visual, dexterity and cognitive disabilities in accessing communication technologies. ${ }^{103}$ Once again, the final version of the ADA represents a watered-down version of the original provisions. Rather than classifying the protection conferred upon disabled people under separate titles, previous drafts were divided into sections concentrated on prohibiting discrimination in a number of environments, including in "access to services or programs". 104 The application of a broad definition of disability to the telecommunications sector would have assisted all disabled people. From this perspective, the ADA represents a missed opportunity for safeguarding the interests of all disabled people to access effectively the communications sector.

Even if the ADA provided disabled people with a stronger degree of protection for accessing the communications sector, disabled people would still be faced with considerable challenges in their search for justice. Although the ADA reflects the social model of disability, the courts conditioned the application of the ADA on the provision of medical evidence, reinforcing the medical approach to disability. ${ }^{105}$ According to Smith, the approach based on medical evidence reflects "a deep-seated scepticism" of disabled people who seek to enforce their rights under equality legislation. ${ }^{106}$ For these reasons, the ADA is seen as providing disabled people with "a hope for equality and access that has not been fulfilled". 107 The courts' reliance on the medical model of disability when dealing with claims under the ADA could be due to the use of the term "impairment" in the statute. 108 As Oliver suggests, the term "impairment" concentrates on the physical or mental condition of individuals and is associated with the medical model of disability, while the term "disability" concentrates on the social barriers faced by people and is, therefore, associated with the social model of disability. ${ }^{109}$ Smith concludes that the use of the term "impairment" in the ADA creates a tension between social and medical concepts of disability ${ }^{110}$ and that the courts' insistence on medical evidence for individuals wishing to rely on the ADA places disabled people "in a position of being pathologized, pitied and therefore disempowered" and overlooks the perception of disabled people as citizens. ${ }^{111}$

10042 USC, s. 12101(a)(8). See Bick, "Americans with Disabilities Act”, n. 88 above, p. 213

101 M O Finnigan Jr et al., "Accommodating cyberspace: application of the Americans with Disabilities Act to the internet" (2007) 75 University of Cincinnati Law Review 1795-826, at p. 1802.

102 F G Bowe, “Access to the information age: fundamental decisions in telecommunications policy" (1993) 21(4) Policy Studies Journal 765-74, at p. 766.

103 Ibid.

104 Colker, “ADA Title III”, n 90 above, p. 382, referring to HR 448 and S 2345 (1988).

105 Scotch, "Models of disability”, n. 25 above, p. 218. See, for example, Sutton v United Air Lines, Inc. 527 US 471 (1999) but note that the narrow definition of disability adopted in Sutton (which relied on the "ameliorative effect of mitigating measures" to determine "whether an impairment substantially limits a major life activity") has been rejected in the ADA Amendments Act of 2008, Public Law 110-325, 25 September 2008.

106 D M Smith, "Who says you're disabled? The role of medical evidence in the ADA definition of disability" (2007) 82(1) Tulane Law Review 1-76, at p. 1.

107 Ibid.

108 Ibid., p. 7.

109 M Oliver, The Politics of Disablement (Basingstoke: Palgrave Macmillan 1990).

110 Smith, "Who says", n. 106 above, p. 11.

111 Ibid. pp. 71-2. 
While the ADA Amendments Act of 2008 relies on a broad definition of disability "constructed ... to the maximum extent permitted by the terms of this Act", 112 this does not necessarily mean that this instrument reflects a social approach to disability, given its continued reliance on the notion of physical and mental "impairment". 113

This section has illustrated that, despite the number of provisions adopted in order to facilitate the access of disabled people to digital television, there is still room for improvement. The measures adopted in the digital television sector tend to focus on the provision of assistance for people with sensory disabilities (particularly hearing disabilities), overlooking the needs of people with other disabilities, such as cognitive or dexterity disabilities. Furthermore, the provision of an effective level of protection for disabled people seeking to enforce their rights under the ADA is affected by the continuing reliance of the courts on the medical definition of disability, which is in strong contrast to the social focus of this Act. The approach adopted by the courts tends to focus on disabled people as disempowered victims and fails to perceive disabled people as citizens. ${ }^{114}$ The final section of this paper calls for a regulatory approach for the communications sector which is focused on citizenship values such as equality and dignity and which aims to protect the rights of disabled people to access digital television as a citizenship right. Before that, however, the following section aims to explore the extent to which the regulatory framework for the communications sector in the UK safeguards the rights of disabled people.

\section{The protection of disability rights in the regulation of digital television in the United Kingdom}

Similar to the American system, the approach adopted in the UK for safeguarding disability rights in the digital television sector tends to concentrate on assisting people with sensory disabilities and provides only a limited level of assistance for people with cognitive or dexterity disabilities. ${ }^{115}$ This limited level of protection is regrettable, particularly given the general duty imposed by the Communications Act $2003^{116}$ on the British communications regulator Ofcom to have regard to the needs of disabled people ${ }^{117}$ when fulfilling its principal duty "to further the interests of citizens in relation to communications matters" and "to further the interests of consumers in relevant markets, where appropriate by promoting competition". 118 The key provisions for safeguarding the rights of disabled people in the digital television context are s. 303 (television services for deaf and visually impaired people), s. 310 (Code of Practice for Electronic Programme Guides (EPGs)) and s. 10 (use of apparatus with ease and without modifications) of the Communications Act. According to s. 303, Ofcom is required to adopt and maintain a code providing guidance on accessibility services for people with hearing disabilities and/or visual disabilities. ${ }^{119}$ Such accessibility

112 Public Law 110-325, 25 September 2008. See 42 USC, s. 3(3)(A).

113 Ibid.

114 Smith, "Who says", n. 106 above, pp. 71-2.

115 For a more detailed discussion of these issues see E Varney, "Disability rights in the communications sector: an examination of digital television regulation in the United Kingdom" (2008) 13(6) Communications Law 187-96.

116 Communications Act 2003, c. 21.

117 Ibid., s. 3(4)(j).

118 Ibid., s. 3(1).

119 Ibid., s. 303(1). 
services include subtitling, signing and audio description. In 2004, Ofcom adopted a Code on Television Access Services (subject to subsequent reviews) ${ }^{120}$ which applies to

licensed public service channels, [digital television] programme services, television licensable content services and restricted television services, as well as any [digital television] programme services provided by the Welsh Authority. ${ }^{121}$

The code also applies to the public television services provided by the BBC. ${ }^{122}$ The Communications Act makes provision for targets with respect to subtitling, signing and audio description, which must be fulfilled from the fifth and the 10th anniversary of the "relevant date" (set in accordance to when a service commenced). ${ }^{123}$ These targets are based on the size of the audience. ${ }^{124}$ However, Ofcom can exempt certain programmes from the obligations to comply with these targets. ${ }^{125}$ The 10 -year targets for broadcasters are generally set at 80 per cent for subtitling, 5 per cent for signing and 10 per cent for audio description. ${ }^{126}$ While the application of the code to both public service broadcasters and commercial broadcasters has been praised in a report on measuring eAccessibility in Europe, ${ }^{127}$ organisations representing the interests of disabled people, such as the Royal National Institute of Blind People (RNIB), have expressed disappointment that the 10 per cent target for audio description is too low ${ }^{128}$ and, therefore, is unlikely to have a significant impact in facilitating the access of people with visual disabilities to digital television. Similar to the American context, the provision on accessibility services for people with hearing disabilities seem much stronger than the level of assistance provided to people with visual disabilities. Despite the existence of guidelines for broadcasters on subtitling, signing and audio description, ${ }^{129}$ the Code on Television Access Services makes no provisions for any technical standards regarding the way in which these accessibility services are made available. ${ }^{130}$ Service providers are merely expected to use "reasonable endeavours" to ensure that the greatest number of people can access television services. ${ }^{131}$ This seems to allow a considerable degree of flexibility in the hands of the industry. The fact that market players often lack the economic incentives to search for interoperable solutions ${ }^{132}$ makes it unlikely that this approach is the most effective for safeguarding the interests of disabled people in the digital television sector.

Similar to the Code on Television Access Services, the Code of Practice on EPGs adopted under s. 310 of the Communications Act is also limited to providing assistance to "people with hearing and/or visual impairments". ${ }^{133}$ This code of practice requires EPG

120 Ofcom (2006) "Television access services review”, at para. 2.1, www.ofcom.org.uk/tv/ifi/codes/statement/.

121 Ofcom (2008) "Code on Television Access Services", at para. 3, www.ofcom.org.uk/tv/ifi/codes/ctas/.

$122 \mathrm{Cl}$. 59, "Agreement between Her Majesty's Secretary of State for Culture, Media and Sport and the British Broadcasting Corporation", July 2006, Cm 6872.

123 Ss. 303(4) and (5) and 305, Communications Act.

124 MeAC, Policy Inventory, n. 48 above, p. 220.

125 S. 303(7), Communications Act.

126 Ofcom, "Code on Television", n. 121 above, para. 8.

127 MeAC, Main Report, n. 1 above, p. 44.

128 "Report of the Joint Committee on the Draft Communications Bill" (Puttnam Report), July 2002, HL Paper 169-1, HC 876-1, para. 313.

129 Ofcom, “Code on Television”, n. 121 above, Annex 2.

130 Ibid, para. 31.

131 Ibid.

132 Communications Committee (2004) "Report from the Inclusive Communications Subgroup" COCOM 04-08, p. 42.

133 Ofcom (2004) "Code of Practice on EPGs", www.ofcom.org.uk/tv/ifi/codes/EPGcode/epgcode.pdf. 
providers to make adjustments to their EPGs, so far as practicable, in order to ensure the access of people with sensory disabilities to these services and to promote awareness on accessibility information on the EPGs. ${ }^{134}$ The failure to include any form of assistance for people with other disabilities, such as cognitive and dexterity disabilities, is disappointing. Organisations such as Age Concern ${ }^{135}$ and Ricability ${ }^{136}$ have called for a wider definition of disability in the regulation of EPGs and for addressing issues such as the use of remote controls in accessing EPGs. As Ricability points out, poorly designed remote controls can constitute a barrier for many disabled people in accessing digital television, ${ }^{137}$ including people with dexterity disabilities.

While the Code of Practice on EPGs makes no provisions for assisting people with dexterity and cognitive disabilities, the assistance conferred to people with sensory disabilities is far from satisfactory. The requirement to provide accessibility solutions only as far as practicable is vague and seems to provide a significant degree of flexibility in the hands of the industry. Furthermore, the code states that "at present, there is limited scope to reconfigure EPGs so as to facilitate their use" by people with sensory disabilities, while the provision of accessibility solutions is reliant on "the future development of EPGs".138 This approach is regrettable, as the code should have provided an increased level of incentives for EPG providers to seek accessibility solutions in order to assist disabled people to take advantage of these facilities. ${ }^{139}$ When justifying its refusal to require EPG providers to take "rapid steps" in improving the accessibility of EPGs "through changes on the set-top box", Ofcom has pointed towards concerns that the hasty implementation of new features on the STB could affect the operation of EPGs. ${ }^{140}$ It is likely that Ofcom's decision was influenced by cost-related concerns raised by EPG providers. ${ }^{141}$ In balancing the interests of disabled people against the interests of the industry, Ofcom should have placed more emphasis on the urgency in the need for accessibility solutions for disabled people in the digital television sector. ${ }^{142}$

While the assistance provided by the Code on Television Access Services and the Code of Practice on EPGs is limited to facilitating the access of people with sensory disabilities to digital television, s. 10 of the Communications Act has the potential to assist all disabled people. This section requires Ofcom to encourage the development of electronic communications apparatus "which is capable of being used with ease and without modification by the widest possible range of individuals (including those with disabilities)". ${ }^{143}$ Ofcom is also under a duty to encourage the wider availability of electronic communications apparatus. ${ }^{144}$ As defined under s. 10(4) of the Communications Act, such

134 Ofcom, "Code of Practice", n. 133 above, para. 6.

135 Age Concern, "Response to the Ofcom Consultation on EPGs" (2004). para. 3.1, www.ofcom.org.uk/ consult/condocs/epg/responses/age_concern.pdf/.

136 Ricability, "Response to the Ofcom Consultation on EPGs" (2004), para. 6.0, www.ofcom.org.uk/ consult/condocs/epg/responses/ricability.pdf.

137 Ibid.

138 RNIB, "Response to the Ofcom Consultation on EPGs", (2004), p. 8, www.ofcom.org.uk/consult/condocs/ epg/responses/rnib2.pdf.

139 Disability Rights Commission, "Response to the Ofcom Consultation on EPGs" (2004), p. 3, www.ofcom.org.uk/consult/condocs/epg/responses/drc.pdf.

140 Ofcom, "Statement on Code on Electronic Programme Guides" (2004) p. 18, www.ofcom.org.uk/ consult/condocs/epg/statement_archived/statement.pdf.

141 Ibid. 19.

142 MeAC, Main Report, n. 1 above, 13.

143 S. 10(1)(a), Communications Act.

144 Ibid., s. 10(1)(b). 
apparatus sends or receives information transmitted by means of an electronic communications network. The Explanatory Notes to s. 10 stresses that under this provision, Ofcom has the potential to encourage the development of easy to use remote controls. ${ }^{145}$ This could represent a step forward in facilitating the access to digital television for people with dexterity disabilities. Nevertheless, the potential impact of this provision in assisting disabled people is limited by the fact that s. 10 merely requires Ofcom to "encourage" the development and availability of easy to use apparatus, without providing the communications regulator with formal regulatory powers to enforce such provisions. ${ }^{146}$ Once again, the reliance on voluntary efforts by the industry overlooks the sense of urgency in developing accessibility solutions for the digital television sector, particularly in light of the switchover to digital television planned to be completed by 2012.147

As the specific provisions for facilitating the access of disabled people to digital television seem focused on assisting people with sensory disabilities, it would be interesting to see the extent to which people with other disabilities could rely on the general equality legislation, in order to challenge the barriers they face in accessing digital television. The Disability Discrimination Act (DDA) 1995 (as amended in 2005) 148 $^{1}$ is the main piece of legislation adopted in the UK for combating disability discrimination. The DDA combats disability discrimination in a number of sectors, including access to information and communication services. ${ }^{149}$ As one of the categories of service providers covered by the Act, broadcasting organisations have the responsibility to ensure that people accessing their services do not face unjustified discrimination on grounds of disability. ${ }^{150}$ Discriminatory treatment includes the refusal to provide a service or the provision of a lower standard of service to a disabled person. ${ }^{151}$ According to s. 21 of the DDA, service providers are placed under a duty to take reasonable steps to ensure that disabled people do not face discriminatory treatment. In complying with this duty, service providers are required, inter alia, to alter particular physical features in their services in order to enable access. ${ }^{152}$ This provision could prove particularly useful for pursuing equality objectives in the digital television sector, for example, by requiring EPG controllers to make their services available to disabled people. ${ }^{153}$ Nevertheless, the duty imposed on service providers by s. 21 is subject to limitations based on financial considerations. ${ }^{154}$

Public authorities, such as the communications regulator Ofcom, are subject to a disability equality duty (DED), requiring them to ensure that disabled people enjoy equal access to services. ${ }^{155}$ They must be proactive in ensuring equal access to services for disabled people and must involve disabled people in the search for solutions. ${ }^{156}$ Furthermore, public authorities are expected to publish yearly reports highlighting the key

145 Explanatory Notes to the Communications Act, para. 42.

146 Ofcom, "Usability in the communications sector" (2008), p. 3, speech by Huw Irranca-Davies MP, Minister for Digital Inclusion, www.ofcom.org.uk/research/usability/usability08/report.

147 Culture, Media and Sports Committee (CMS), "Analogue switch-off: a signal change in television" (March 2006), HC Paper 650-I.

148 Disability Discrimination Act 1995, c. 50 (as amended by the Disability Discrimination Act 2005 c. 13).

149 Ibid., s. 19 (3)(b)(c).

150 Ibid., s. 19; DRC, "Revised Code of Practice on Part 3 DDA" (2006), para. 3.3.

151 Ss. 19 and 20, DDA.

152 Ibid., s. 21(2).

153 Ofcom, "Code on Television", n. 121 above, p. 35.

154 S. 21(6) and (7), DDA.

155 Ibid., s. 49A.

156 MeAC, Policy Inventory, n. 48 above, p. 228. 
steps taken for achieving the equality objectives. ${ }^{157}$ The DED has the potential to act as "a powerful tool" in promoting accessibility for disabled people in the communications sector. ${ }^{158}$ As indicated in the first disability equality scheme issued by Ofcom in 2006, the issue of access to electronic communications is perceived as a priority area for promoting disability equality. ${ }^{159}$ It is interesting to note that the Equality Bill ${ }^{160}$ aims to introduce a streamlined equality duty placed on public authorities, covering not only the existing duties regarding disability, gender and race but extending to age, gender reassignment, religion or belief, and sexual orientation. ${ }^{161}$ A number of organisations representing disabled people have stressed the need to ensure that this extended duty does not weaken the existing $\mathrm{DED}^{162}$ and does not lead to the situation where public authorities "cherry-pick which activities they needed to undertake . . . leav[ing] disabled people at the bottom of the political agenda". 163

While, at least at a theoretical level, the DDA has the potential to assist disabled people in challenging access barriers to the digital television sector, the practical benefits of this Act for the digital television sector are yet to be seen. Disabled people wishing to rely on the application of the DDA to the digital television sector are not aided by the absence of case law covering this issue. ${ }^{164}$ Furthermore, as Carmichael et al. suggest, the provisions designed to ensure that disabled people do not face discrimination in accessing services are seen as "secondary" to the definition of circumstances which allow service providers to justify discriminatory treatment. ${ }^{165}$ Another potential difficulty could be posed by the fact that this Act adopts a medical approach to disability. Section 1(1) of the DDA defines disability as "a physical or mental impairment which has a substantial and long-term adverse effect" on the ability of a person "to carry out normal day to day activities". Cases brought on the basis of the DDA can become focused on whether a claimant has an impairment which satisfies the definition of disability put forward by the Act, rather than on removing the social barriers to participation faced by disabled people. ${ }^{166}$ Unfortunately, there is no indication that future legislative developments will depart from the medical model of disability in favour of the social model. The government response to the consultation on the Equality Bill (which was subsequently introduced in Parliament in the 2008-2009 session) ${ }^{167}$ has stressed that disability discrimination law should protect "only those people who are disabled in the generally recognised sense of the term i.e. because they have a longterm or permanent impairment, with substantial adverse effect". ${ }^{168}$ The definition of disability adopted in cl. 6 of the Equality Bill continues to place emphasis on the link between disability and impairment. ${ }^{169}$ This continued emphasis on impairment and the

157 MeAC, Policy Inventory, n. 48 above, p. 228.

158 Ibid., p. 227.

159 Ofcom, "Disability equality scheme" (2006), para. 2.3, www.ofcom.org.uk/consult/condocs/des/statement/ desstatement.pdf.

160 Equality Bill 2008-2009, Bill 85 08-09, introduced in the House of Commons on the 27 April 2009.

161 Cl. 143(6), Equality Bill.

162 Government Equalities Office, “The Equality Bill - government response to the consultation” (July 2008), Cm 7454, p. 18.

163 Ibid., p. 19 (referring to the submission by the Association of Disabled Professionals).

164 A Carmichael et al., "Digital switchover or digital divide: a prognosis for usable and accessible interactive digital television in the UK" (2006) 4 Universal Access in the Information Society 404-16, at p. 408.

165 Ibid.

166 Monaghan, Equality Law, n. 26 above, para. 5.76.

167 Equality Bill, n. 160 above.

168 Government Equalities Office, “The Equality Bill”, n. 162 above.

169 Cl. 6(1), Equality Bill. 
reliance on medical evidence for individuals wishing to rely on equality legislation before the courts reflects a perception of disabled people as disempowered victims and overlooks the perception of disabled people as citizens. ${ }^{170}$ It is very doubtful that the emphasis of the legislative framework on individual litigants who have to prove that their "impairment" fits the "recognised" definition of disability ${ }^{171}$ can achieve equality in practice to the same extent as the social model would. As discussed in the following section, a preferable alternative to individual litigation for tackling the barriers faced by disabled people in accessing digital television would be the provision of a regulatory framework which reflects citizenship values such as equality and dignity.

\section{Lessons to be learned?}

The regulatory frameworks for electronic communications in both the United States of America and the United Kingdom have already taken important steps for facilitating the access of disabled people to digital television. However, as illustrated in parts two and three of this study, more needs to be done to ensure that all disabled people enjoy equal access to digital television. In the absence of positive steps towards this aim, technological developments will have the undesirable effect that they "disempower rather than empower and to isolate rather than integrate" disabled people. ${ }^{172}$ Advances in digital technology could, therefore, bear the risk of creating barriers for disabled people in accessing information and lead to "the creation of disability and the construction of dependency relationships". ${ }^{173}$ This section calls for a regulatory framework focused on tackling the social barriers faced by disabled people in accessing digital television and on safeguarding citizenship values such as equality. The discussion reflects on the key challenges associated with the accessibility provisions in the USA and the UK and calls for the need to tackle the hierarchy of disabilities in the regulation of digital television, in order to ensure that all disabled people enjoy effective access to information. The analysis also stresses the importance of the social model of disability in tackling the access barriers faced by disabled people in the digital television context and calls for a regulatory framework which emphasises the rights of disabled people to access digital television as citizenship rights, and which prioritises these rights over the economic interests of the industry.

The regulatory provisions for digital television in both the USA and the UK seem focused on addressing the needs of people with sensory disabilities, overlooking the needs of people with other disabilities such as cognitive or dexterity disabilities. Whilst ensuring an effective level of protection for people with sensory disabilities is important, it is also important that the regulatory framework for digital television addresses the needs of all disabled people. It is essential that all disabled people have effective access to information, which would enable them to participate effectively in society as citizens. Unfortunately, the regulatory framework for the digital television sector is affected by a hierarchy of disabilities. Deal indicates that non-disabled people's attitudes towards disabled people have been "predominately negative" and that "behaviours appear to vary" according to the nature of disability. ${ }^{174}$ People with cognitive disabilities such as learning disabilities

170 Smith, "Who says", n. 106 above, p. 72.

171 Monaghan, Equality Law, n. 26 above, para. 5.76.

172 L Johnson and E Moxon, "In whose service? Technology, care and disabled people: the case for a disability politics perspective" (1998) 13(2) Disability and Society 241-58, at p. 246 (quoting Oliver).

173 B Sapey, "Disablement in the informational age" (2000) 15(4) Disability and Society 619-36, at p. 619 (referring to works by Finkelstein and by Oliver).

174 M Deal, “Disabled people's attitudes towards other impairment groups: a hierarchy of impairments" (2003) 18(7) Disability and Society 897-910, at p. 898. 
encounter an increased level of difficulty towards acceptance in society. ${ }^{175}$ According to Deal, the hierarchy of disabilities is also reflected in the attitudes of disabled people, as they "do not always wish to be associated with other impairment groups for a variety of complex reasons", including stigma and the perception that people with other disabilities have got a different agenda with regards to issues such as access to services. ${ }^{176}$ Similarly, Fox and Kim argue that certain groups within the disability population "appear to lag behind their peers in important indicators of independent living". ${ }^{177}$ This could be due to the fact that, despite the growing perception of disability as being attributed to social barriers, learning disability continues to be associated with the medical approach. ${ }^{178}$ Goodley stresses the need to ensure that cognitive disabilities such as learning disabilities are perceived from a social rather than a medical perspective. ${ }^{179}$ In a study about the citizenship of people with learning disabilities, Walmsley indicates that these citizens "have often been marginalised" but that their active involvement in society is far more than just "an empty dream". ${ }^{180}$ As Walmsley suggests,

despite ideological and structural barriers... some people with learning difficulties are learning skills which enable them to participate in a meaningful way in decisions about their own lives and in activities which might be categorised as pertaining to citizenship. ${ }^{181}$

It is, therefore, important to ensure that their interests are effectively taken into account by any regulatory framework designed to facilitate the access of all citizens to information.

Both the United Kingdom and the United States of America need to move away from the hierarchy of disabilities in the regulation of digital television and need to ensure that accessibility solutions reflect a wide range of disabilities. The solution rests with the adoption of a regulatory framework for the digital television sector based on citizenship values such as equality and human dignity. ${ }^{182}$ In such a regulatory framework, there is no room for a hierarchy of disabilities. As Bynoe et al. point out, in safeguarding the rights of disabled people, facilities must be organised around "a framework of enforceable citizenship rights" and emphasis must be placed on facilitating the active participation of all citizens in society. 183 The citizenship values of equality and human dignity are inherent in every human being and any legislative framework committed to safeguarding these values aims to ensure that "everybody is treated as having value or worth". ${ }^{184}$ A formal approach to equality seeks to ensure that individuals are not treated less favourably because of a specified characteristic ${ }^{185}$ and adopts a reactive approach to discrimination, providing individuals with the right to sue if they have been treated in a discriminatory manner. ${ }^{186} \mathrm{On}$ the other hand, the substantive vision of equality is concerned with tackling "systematic"

175 Deal, "Disabled people's attitudes", n. 174 above.

176 Ibid., pp. 903-4.

177 F H Fox and K Kim, "Understanding emerging disabilities" (2004) 19(4) Disability and Society 323-37, at p. 326.

178 D Goodley, “Learning difficulties', the social model of disability and impairment: challenging epistemologies" (2001) 16(2) Disability and Society 207-31, at p. 210.

179 Ibid.

$180 \mathrm{~J}$ Walmsley, “Talking to top people': some issues relating to the citizenship of people with learning difficulties" (1991) 6(3) Disability and Society 219-31, at p. 220.

181 Ibid.

182 Feintuck, The Public Interest, n. 21 above.

183 J Bynoe et al., Equal Rights for Disabled People. The case for a new law (London: IPPR 1991), p. 3.

184 S Fredman, “Equality: a new generation?” (2001) 30(2) Industrial Law Journal 145-68, at p. 155.

185 Ibid., p. 154.

186 Ibid., p. 164. 
forms of discrimination rooted in society and with ensuring social inclusion for underrepresented groups. ${ }^{187}$ Substantive equality adopts a proactive approach to tackling discrimination and to promoting equality, stressing the need to alter practices and structures in order to "bring about real change". 188 The concept of human dignity plays an important role in ensuring substantive equality. ${ }^{189}$ Despite a certain degree of reluctance from some critics who stress that the term is too ambiguous, the concept of human dignity can act as a powerful tool in human rights discourse ${ }^{190}$ and in enhancing the protection of fundamental values such as equality of citizenship. ${ }^{191}$ This concept is often linked with the notion of "autonomy" or "the freedom of the individual to choose according to his view of the "good life"'192 and has been defined as "the right not to be disadvantaged or humiliated by virtue of one's subjective characteristics". 193 The adoption of a regulatory framework for the digital television context based on the notions of substantive equality and human dignity would ensure that such measures do not differentiate between the levels of protection conferred to different disabilities.

The social model of disability should prevail in the regulatory framework for dealing with disability discrimination in both the USA and the UK. Scotch warns against the risks associated with the medical approach to disability, stressing that a perception of disabled people as having "pathological attributes typically linked to incapacity and dependency" places the onus on the need for disabled people to "overcome" their disabilities in order to fit into mainstream society. ${ }^{194}$ Rather than perceiving disabled people as citizens who face social barriers to participation, disabled people are perceived as "victims" who fail to fit into mainstream society. 195 There is a significant difference between the perception of disabled people as victims (associated with the medical model) and their perception as citizens entitled to equal treatment (associated with the social model). ${ }^{196}$ Measures which perceive disabled people as victims tend to adopt a reactive approach to disability discrimination, relying on individual litigation whenever discrimination has occurred. Nevertheless, an approach based on individual litigation relies on action by an individual "with the energy and resources to bring a claim" and depends on the potential to trace inequalities to a particular perpetrator. ${ }^{197}$ Furthermore, if a claimant is successful, the impact of the case is limited to providing compensation for that particular claimant, without any obligation to tackle the social barriers that gave rise to disability discrimination in the first place and which are likely to affect disabled people as a group. 198 On the other hand, measures which perceive disabled people as citizens are rooted in a framework of principles based on values, such as equality and the protection of human dignity, ${ }^{199}$ and adopt a proactive approach to

187 Chalmers et al., European Union Law, n. 24 above, pp. 897 and 916.

188 Fredman, "Equality”, n. 184 above, p. 163.

189 Ibid., p. 155.

190 C McCrudden (ed.), Anti-Discrimination Law (Dartmouth: Ashgate 2004).

191 D G Réaume, "Discrimination and dignity” (2003) 63 Louisiana Law Review 645-95.

192 Fredman, “Equality”, n. 184 above, p. 155.

193 Z Apostolopoulou, "Equal treatment of people with disabilities in the EC: what does 'equal' mean?” (2004) Jean Monnet Working Paper 09/04.

194 Scotch, "Models of disability", n. 25 above, p. 219.

195 Gregg, "Policy-making”, n. 19 above, p. 538.

196 Fredman, "Equality", n. 184 above, p. 164.

197 S Fredman, Human Rights Transformed: Positive rights and positive duties (Oxford: OUP 2008), p. 189.

198 Ibid., p. 190.

199 Feintuck, The Public Interest, n. 21 above. 
achieving equality in practice. ${ }^{200}$ Such measures focus on systematic cases of discrimination and are designed to protect the rights of groups rather than just individuals. ${ }^{201}$ The proactive approach calls for cooperation amongst all stakeholders, including policy makers and service providers. ${ }^{202}$ This approach advocates social change and concentrates on the removal of barriers which hinder participation in society. ${ }^{203}$ In the digital television sector, the social model of disability provides an effective approach for tackling the access barriers faced by disabled people and calls for positive action in order to ensure that all disabled people enjoy effective access to information. This may require the need to "reshape society" in order to "include the whole spectrum of abilities" 204 but, as Gooding suggests, this is not an impossible task if it is rooted in a broad framework of rights for disabled people. ${ }^{205}$

The regulatory frameworks in both the USA and the UK do not place sufficient emphasis on the rights of disabled people to access digital television as citizenship rights. In fact, in the UK, the absence of "a coherent concept of the public interest" in the Communications Act 2003 has led to criticism that the British system lacks "solid foundations" for regulatory intervention in the pursuit of citizenship values. ${ }^{206}$ While the Act imposes on Ofcom the general duty to have regard to the needs of disabled people 207 when fulfilling its principal duty to safeguard the interests of citizens and consumers in the communications sector, it is not clear from the language of the Act whether disabled people are perceived as citizens or as consumers. Yet, these interests are not always synonymous and regulatory intervention to meet consumer interests could overlook wider citizenship concerns such as the need to safeguard equality and human dignity. In a recent consultation where Ofcom aims to clarify its dual responsibility to protect citizenship and consumer interests, the key provisions designed to facilitate the access of disabled people to digital television are classified under the heading "duties to further citizenship interests".208 Nevertheless, Ofcom stresses that citizenship and consumer interests can often overlap and that having access to services as consumers is often a prerequisite for having access to information in order to participate in society as citizens. ${ }^{209}$ Potential difficulties are, however, likely to arise in the case of conflict between citizenship and consumer interests. At the moment, Ofcom is entrusted with "wide-ranging and largely unstructured discretion" 210 to resolve the conflict in the manner "they think best in the circumstances". 211 As Feintuck indicates, a preferable approach would have been to prioritise citizenship interests over the interests of consumers, as suggested by the Puttnam Report, ${ }^{212}$ as failure to do so risks leaving citizenship interests "vulnerable to defeat by

200 Fredman, "Equality”, n. 184 above, p. 164.

201 Ibid.

202 Fredman, Human Rights Transformed, n. 197 above, p. 190.

203 Fredman, "Equality”, n. 184 above, p. 150.

204 C Gooding, Disabling Laws, Enabling Acts. Disability rights in Britain and America (London: Pluto Press 1994), p. 3. 205 Ibid., p. 30.

206 M Feintuck, "Walking the high-wire: the UK's Draft Communications Bill” (2003) European Public Law 9(1), pp. 105-24, at p. 107.

207 S. 3(4)(j), Communications Act 2003.

208 Ofcom, "Citizens, communications and convergence" (2008), para. 3.9, www.ofcom.org.uk/consult/ condocs/citizens/discussionpaper.pdf.

209 Ibid., para. 2.22.

210 M Feintuck, "Protecting non-commodity values in 'the public interest"' in T Prosser et al. (eds), Law, Economic Incentives and Public Service Culture, Working Paper 05/129 (CMPO: Bristol 2005), pp. 70_80.

211 S. 3(7), Communications Act 2003.

212 Puttnam Report, n. 128 above. 
other factors". ${ }^{213}$ Furthermore, by prioritising citizenship interests over the interests of consumers, the Communications Act could have avoided any ambiguity as to the range of values protected in any particular provisions adopted under the Act. ${ }^{214}$ Due to the absence in the Communications Act of any specific reference to the rights of disabled people as citizenship rights, the provisions adopted under ss. 10, 303 and 310 of the Act tend to reflect a perception of disabled people as "users" rather than citizens. Therefore, these provisions fail to emphasise the citizenship values of equality, dignity and individual autonomy as the basis for regulatory intervention designed to facilitate the access of disabled people to information. A positive step towards acknowledging the need to safeguard citizenship values in the communications sector is reflected in the recent House of Lords Select Committee report on the Ownership of the News, ${ }^{215}$ which recommended in the context of media mergers that "when Ofcom considers . . . public interest . . . considerations . . . it should be required to put the needs of the citizen ahead of the needs of the consumer". ${ }^{216}$ While this development, limited to the context of media mergers, provides a certain degree of optimism, more needs to be done in order to ensure that citizenship values are prioritised over consumer interests in all areas of the communications sector, including in the provision of access for disabled people to digital television.

The absence of a clearly defined framework of principles to assist the communications regulator in the provision of access for disabled people to digital television has also affected the American system. While the FCC is entrusted with acting in pursuit of the "public interest" 217 and licensed broadcasters are required to broadcast "in furtherance of the "public interest", 218 the public interest notion is ambiguous. ${ }^{219}$ Given this ambiguity, there is a significant risk that this concept can be misused by political or commercial forces in the pursuit of self-interest. ${ }^{220}$ According to Feintuck, this risk can be avoided in a regulatory framework that puts forward a clear definition of the public interest, reflecting democratic values such as equality of citizenship. ${ }^{221}$ Furthermore, the citizenship values inherent in the public interest concept can play an important role in interpreting regulatory provisions in the communications sector, which deal with the issue of access for disabled people.

The regulatory frameworks in both the USA and the UK reveal a tendency of the regulators to side with industry interests, often at the expense of those of citizens. This tendency is reflected, for example, in the watered-down measures adopted for the provision of access for disabled people to digital television. These provisions are likely to be the result of financial considerations put forward by the industry with regards to the costs of accessibility provisions. Walker and Townsend suggest that the integration of disabled people is likely to face not only "environmental and psychological barriers" but also considerable financial barriers. ${ }^{222}$ Nevertheless, as Shakespeare indicates, society must be prepared to make additional investments in order to address the barriers faced by disabled people. ${ }^{223}$

213 Feintuck, "Protecting non-commodity values", n. 210 above.

214 Feintuck, "Walking the high-wire", n. 206 above.

215 House of Lords, Select Committee on Communications, report on the Ownership of the News, June 2008, HL Paper 122-I.

216 Ibid., para. 275.

217 Feintuck, "Walking the high-wire", n. 206 above, p. 122.

21847 USC, s. $301 \mathrm{ff}$. See Varona, "Changing channels", n. 36 above, p. 4.

219 D Freedman, The Politics of Media Policy (Cambridge: Polity Press 2008), at p. 64.

220 Feintuck, The Public Interest, n. 21 above, p. 28.

221 Ibid., p. 58.

222 A Walker and P Townsend, Disability in Britain: A manifesto of rights (Oxford: Martin Robertson 1981), p. 16.

223 T Shakespeare, Disability Rights and Wrongs (London: Routledge 2006), p. 66. 
There is a danger that citizenship interests are overlooked in favour of the economic interests of the industry. This could be due to strong lobbying from the industry, influencing policy making. According to Varona, the influence exercised by the broadcasting industry in the United States of America is manifested in relation to both the FCC and Congress, arguing that the FCC has been "captured" by industry interests and that Congress is "so beholden to broadcast interests that its link to broadcasters has been characterised as that of an "umbilical cord". 224 As the legislative history of the Telecommunications Act and of the ADA illustrates, while Congress had the chance to go beyond closed captions in order to authorise the FCC to pursue the interests of all disabled people in accessing digital television, it chose not to do so. The influence exercised by commercial players over Congress and the FCC renders the chances of adopting "heightened 'public interest' requirements" for the communications sector which would benefit, disabled people, and others, to be "remote at best". 225 Similar concerns regarding the influence of the industry over the regulatory realm have been expressed in relation to the $\mathrm{UK},{ }^{226}$ illustrated, for example, by the deregulatory nature of the Communications Act and the "unwillingness" of policy makers "to take tough decisions" 227 in favour of citizenship interests. ${ }^{228}$ There is a significant discrepancy between the influence exercised over the regulatory realm by commercial players on the one hand and the public on the other. Kanayama stresses that "typically, the regulated business and industry groups have the loudest voices among the interest groups".229 Industry groups are well organised and benefit from sufficient resources which enable them to influence policy making. ${ }^{230}$ On the other hand, citizenship voices are much weaker, due, in part, to high participation costs, such as legal fees, limited resources and lack of expertise in technical proceedings. ${ }^{231}$

The regulatory framework for the communications sector needs to facilitate participation in policy making from groups representing the interests of disabled people. Campbell highlights the importance of ensuring that disabled people are powerful enough to influence their own future, ${ }^{232}$ while Evans indicates that "those who know best the needs of disabled people and how to meet those needs are disabled people themselves".233 Furthermore, Oliver acknowledges that new technologies have the potential either to empower or confine disabled people and that the disability movement can play a crucial role in ensuring that disabled people are empowered by technological advances. ${ }^{234}$ The adoption of the TDCA in the United States of America represents a success story for the involvement of disability groups in policy making in the communications sector. ${ }^{235}$

224 Varona, "Changing channels", n. 36 above, pp. 82 and 84.

225 Ibid., p. 91.

226 E Varney, "Winners and losers in the communications sector: an examination of digital television in the United Kingdom” (2005) 6(2) Minnesota Journal of Law, Science and Technology 645-85.

227 T Crane, "OFCOM - a new order for communications regulation or a bureaucratic nightmare" (2003) 9(2) Computer and Telecommunications Law Review 37-40, at p. 37.

228 Feintuck, "Walking the high-wire", n. 206 above, pp. 107-08.

229 Kanayama, "Leaving it", n. 78 above, p. 186.

230 Ibid.

231 Ibid.

232 J Campbell, "Valuing diversity: the disability agenda - we've only just begun" (2002) 17(4) Disability and Society $471-8$, at p. 472.

233 J Evans, "How disabled people are excluded from independent living" (2002) presentation for Madrid Conference on European Disabled People, 21 March.

234 Oliver, Politics of Disablement, n. 109 above. See Johnson and Moxon, "In whose service?", n. 172 above, p. 255.

235 Bowe, “Access", n. 102 above, p. 766. 
Organisations representing people with hearing disabilities played a very active role in the debate about closed captioning, advancing their "direct experience" in using this technology and resisting calls from the industry for the imposition of a lower level of obligations on television manufacturers. ${ }^{236}$ Unfortunately, the success story for social forces in the adoption of the TDCA represents the exception rather than the rule.

In order to ensure that the citizenship interests of disabled people are not sacrificed in favour of the economic interests in the industry, it is important that the regulatory framework for the communications sector facilitates the involvement of disabled people in policy making. Positive steps towards this aim have already been taken in the United Kingdom in the Communications Act. For example, in issuing and reviewing the Code on Television Access Services, s. 304 of the Act requires Ofcom to consult, among others, persons representing the interests of people with sensory disabilities. It is, however, necessary that the consultation process has a real impact and that the views of disabled people are adequately taken into account in policy making for the electronic communications sector. It is also important to ensure that the consultation process involves organisations representing the needs of all disabled people, including people with cognitive and dexterity disabilities.

The regulatory framework should also ensure that citizenship rights are prioritised over the interests of the industry in policy making. The success of such provisions may depend on broader social changes. As Gooding suggests, we should "not ask too much of individual pieces of legislation", given that a genuine commitment to equality can be achieved only within a "context of broader economic and social change". 237 Similarly, Kanayama notes that the promotion of accessibility solutions for disabled people may require a change in people's perceptions of these issues, as a strong level of public support for accessibility solutions is an effective way to "overcome organised opposition like industry groups". 238 A regulatory framework which ensures that disabled people have a strong voice in policy making is an important step towards achieving these objectives. ${ }^{239}$

\section{Conclusion}

The regulatory frameworks for electronic communications in both the USA and the UK reflect a hierarchy of protection for disability rights of access to digital television. The key accessibility provisions adopted for the digital television sector tend to concentrate on assisting people with sensory disabilities, failing to address the needs of people with other disabilities, such as dexterity or cognitive disabilities. Whist ensuring an effective degree of protection for people with sensory disabilities is important, it is disappointing that the interests of people with other disabilities are overlooked, especially given the growing importance that ICTs play in people's everyday life. ${ }^{240}$ This article has stressed the need for a regulatory framework for the electronic communications sector based on democratic values such as equality of citizenship, ${ }^{241}$ arguing that under such a framework there is no room for a hierarchy of disability rights. Such a regulatory framework would also perceive disabled people as empowered citizens rather than vulnerable consumers and would adopt a proactive approach for tackling the barriers faced by disabled people in accessing digital

236 Gregg, "Policy-making", n. 19 above, p. 545.

237 Gooding, Disabling Laws, n. 204 above, p. 29.

238 Kanayama, "Leaving it", n. 78 above, p. 193.

239 C Barnes and M Oliver, "Disability rights: rhetoric and reality in the United Kingdom" (1995) 10(1) Disability and Society, 111-16.

240 Goggin and Newell, Digital Disability, n. 9 above, p. 4.

241 Feintuck, The Public Interest, n. 21 above. 
television, reflecting therefore a social approach to disability. Despite the positive measures adopted in both the USA and the UK towards ensuring an inclusive society, the current regulatory frameworks in both jurisdictions do not go far enough in safeguarding the rights of disabled people to access digital television as citizenship rights. In fact, both jurisdictions reflect a considerable degree of influence exercised by the telecommunications industry over the regulatory realm, often at the expense of citizenship interests. In order to redress the balance in favour of citizenship rights and to ensure that the interests of disabled people are effectively protected in the electronic communications sector, it is essential that the regulatory framework for this sector facilitates the involvement of disabled people in policy making and prioritises citizenship rights over the economic interests of the industry. 